\title{
Alternative routes of enzymic cyanide metabolism in Pseudomonas fluorescens NCIMB 11764
}

\author{
Daniel A. Kunz, Chien-Sao Wang and Jui-Lin Chen \\ Author for correspondence: Daniel A. Kunz. Tel: +1 8173820595 . Fax : +1 8175653821.
}

Microbiology Division, Department of Biological Sciences, University of North Texas, Denton, Texas 76203
Cell-free extracts from Pseudomonas fluorescens NCIMB 11764 catalysed the degradation of cyanide into products that included $\mathrm{CO}_{2}$, formic acid, formamide and ammonia. Cyanide-degrading activity (CDA) was localized to cytosolic cell fractions and was observed at substrate concentrations as high as $100 \mathrm{mM}$ (2600 $\mathrm{mg} \mathrm{CN}^{-} \mathrm{I}^{-1}$ ). At least two different CDAs could be distinguished by: (i) the determination of reaction product stoichiometries, (ii) requirements for NADH and oxygen, and (iii) kinetic analysis. The first activity produced $\mathrm{CO}_{2}$ and $\mathrm{NH}_{3}$ as reaction products, was dependent on oxygen and NADH for activity, and displayed an apparent $K_{m}$ for cyanide of $1.2 \mathrm{mM}$. The second activity generated formic acid (and $\mathrm{NH}_{3}$ ) plus formamide as reaction products, was oxygen independent, and had an apparent $K_{m}$ of $12 \mathrm{mM}$ for cyanide. The first enzymic activity was identified as cyanide oxygenase as previously described [Harris, R. E. \& Knowles, C. J. (1983) FEMS Microbiol Lett 20, 337-341] whereas the second activity is believed to consist of two enzymes, a cyanide nitrilase (dihydratase) and hydratase (EC 4.2.1.66). In addition to these enzymes, cyanide-grown cells were also induced for formate dehydrogenase

(EC 1.2.1.2) thereby providing a means of recycling NADH utilized by cyanide oxygenase. A mutant strain having lost the ability to grow on cyanide as a nitrogen source was isolated and shown to be defective in cyanide oxygenase, but not the cyanide nitrilase/hydratase enzymes. This finding together with results showing that the substrate affinity of cyanide oxygenase was tenfold greater than for the nitrilase/hydratase enzymes, indicates that it is this enzyme that is most important in cyanide assimilation. A cyanate-defective mutant was also isolated and shown to be unaffected in cyanide assimilation, indicating that the metabolism of these two compounds is physiologically distinct.

Keywords: Pseudomonas fuorescens, cyanide oxygenase, nitrilase/hydratase, formate dehydrogenase

\section{INTRODUCTION}

Pseudomonas fluorescens NCIMB 11764 is capable of growth on cranide $\left(\mathrm{CN}^{-} / \mathrm{HCN}\right)$ as the sole nitrogen source (Harris \& Knowles, 1983a). Growth requires that cyanide be enzymically converted to ammonia which, is then readily assimilated into cellular nitrogen. Harris \& Knowles (1983b) first reported the conversion of cyanide into ammonia and $\mathrm{CO}_{2}$ by cell-free extracts from this organism. These findings were confirmed in our lab-

Abbreviations: CDA, cyanide-degrading activity; HSS, high-speed supernatant; Tcn, tetracyanonickelate (II). oratory using intact cells, but formate and formamide were identified as additional reaction products (Kunz et al., 1992). Furthermore, whereas formate and formamide accumulated under both aerobic and anaerobic conditions, $\mathrm{CO}_{2}$ production was shown to be exclusively an oxygen-dependent process. The latter observation is consistent with earlier findings reported by Knowles and coworkers, who proposed that the enzyme responsible for cyanide oxidation in NCIMB 11764 was an oxygenase (Fig. 1) (Harris \& Knowles, 1983b; Knowles \& Bunch, 1986; Knowles, 1988). These investigators further proposed that cyanate was a metabolic intermediate, and subsequent studies showed that an enzyme resembling 


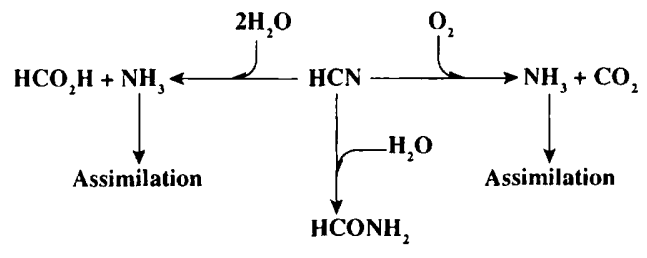

Fig. 1. Routes of cyanide assimilation in P. fluorescens NCIMB 11764.

cyanase (EC 4.3.99.1) could be detected in crude extracts of cyanate-grown NCIMB 11764 cells (Kunz \& Nagappan, 1989). However, this enzyme was not present in cyanide-grown cells implying that cyanate and cyanase are not involved in cyanide assimilation (Dorr \& Knowles, 1989; Nagappan, 1992). The identification of formate and formamide as additional reaction products suggested that in addition to a putative cyanide oxygenase, other enzymes capable of attacking cyanide were also elaborated by this organism. As illustrated in Fig. 1, these included a cyanide nitrilase (dihydratase) responsible for formate and ammonia production, and a cyanide hydratase yielding formamide. Formamide was eliminated as a possible precursor of formate since its further degradation by either intact cells or cell extracts was not observed (Kunz et al., 1992). In this paper we report the recovery of cyanide-degrading activities (CDAs) in cell-free extracts consistent with the existence of these enzymes in NCIMB 11764. That separate enzymic reactions are involved is indicated by results showing that both the products of conversion and kinetics varied with the reaction conditions. In addition to the description of two different CDAs, evidence for the induction of formate dehydrogenase is also reported. Finally, the isolation of mutants defective in cyanide and cyanate utilization is described. Their properties establish the physiological role of cyanide oxygenase in cyanide assimilation and further exclude a role for cyanate as a metabolic intermediate.

\section{METHODS}

Organisms and growth conditions. P. fluorescens NCIMB 11764 has been described in previous communications (Harris \& Knowles, 1983a, b; Kunz et al., 1992). Cells were grown in a minimal salts medium using the fed-batch cultivation procedure described by Kunz et al. (1992). In this procedure glucose $(20 \mathrm{mM})$ is supplied as the carbon source and $\mathrm{KCN}$ is added at sub-toxic levels ( 2 additions per day to give $0 \cdot 125 \mathrm{mM}$ each). Cells were harvested by centrifugation after $3 \mathrm{~d}$ incubation and washed twice in $50 \mathrm{mM} \mathrm{Na}{ }_{2} \mathrm{HPO}_{4} / \mathrm{KH}_{2} \mathrm{PO}_{4}(\mathrm{Na}-\mathrm{K})$ buffer, $\mathrm{pH} 7 \cdot 0$. Cells induced for $\mathrm{CDA}$ were obtained by collecting cells 3-5 h after the addition of $\mathrm{KCN}(0 \cdot 1 \mathrm{mM})$ to a 24 -h-old batch culture that had been grown on $\mathrm{NH}_{4} \mathrm{Cl}(1 \mathrm{mM})$. Washed cell pellets were stored at $-70^{\circ} \mathrm{C}$ until use.

Mutant strains of NCIMB 11764 that had lost the ability to grow on cyanide (JL102) or cyanate (ON101) as the sole nitrogen source were obtained by nitrosoguanidine mutagenesis and penicillin enrichment. The two mutants were obtained from separate mutagenesis performed as follows. A $50 \mathrm{ml}$ overnight culture grown in minimal medium containing glucose $(20 \mathrm{mM})$ as the carbon source and $\mathrm{NH}_{4} \mathrm{Cl}(1 \mathrm{mM})$ as the nitrogen source (minimal glucose-ammonia) was harvested and washed twice with Na-K phosphate buffer, $\mathrm{pH} 7 \cdot 0$. These cells were then resuspended in $50 \mathrm{ml} 0.1 \mathrm{M}$ sodium citrate buffer, pH $5 \cdot 5$, containing $100 \mu \mathrm{g} N$-methyl- $N^{\prime}$-nitro- $N$-nitrosoguanidine $\mathrm{ml}^{-1}$ and incubated for $30 \mathrm{~min}$ at $30^{\circ} \mathrm{C}$ on a rotary shaker. Cells were removed by centrifugation and washed twice in the same buffer before being resuspended in $50 \mathrm{ml}$ minimal glucoseammonia medium and grown overnight. This culture was harvested and the cells washed twice in $\mathrm{Na}-\mathrm{K}$ phosphate buffer, $\mathrm{pH} 7 \cdot 0$, before being inoculated into $50 \mathrm{ml}$ minimal glucose supplied either with tetracyanonickelate (II)(Tcn; $1 \mathrm{mM}$ ) or with cyanate (KOCN; $1 \mathrm{mM}$ ) as the sole nitrogen source. Procedures for the growth of NCIMB 11764 on Tcn (Rollinson et al., 1987; Silva-Avalos et al., 1990) and KOCN (Kunz \& Nagappan, 1989) have been described. After $12 \mathrm{~h}$ growth, mutant enrichment was achieved by adding penicillin $G$ $\left(10000 \mathrm{~L} \mathrm{ml}^{-1}\right)$ and $\mathrm{D}$-cycloserine $\left(0 \cdot 2 \mathrm{mg} \mathrm{ml}^{-1}\right)$ and allowing cultures to incubate for an additional $12 \mathrm{~h}$, during which cell lysis occurred. At this time the cells were harvested and plated to minimal glucose agar plates containing $\mathrm{NH}_{4} \mathrm{Cl}(1 \mathrm{mM})$. Cyanide- or cyanate-defective mutants were then detected after replicating colonies to plates containing either $\mathrm{Tcn}, \mathrm{KCN}$ or $\mathrm{KOCN}$ as the sole nitrogen source. These substrates were added to minimal glucose agar plates at $1 \mathrm{mM}$, except for $\mathrm{KCN}$, which was supplied as vapour as described by Harris \& Knowles (1983a).

Preparation of cell extracts. Washed cells contained in $\mathrm{Na}-\mathrm{h}$ phosphate buffer, pH 7.0 (1.0 g per $2 \mathrm{ml}$ buffer $)$, were broken in a French Press at 20000 p.s.i. (138 MPa). A small amount of deoxyribonuclease $\left(20 \mu \mathrm{g} \mathrm{ml}^{-1}\right)$ was added to the resultant viscous liquid and the preparation was centrifuged at $30000 \mathrm{~g}$ for $30 \mathrm{~min}$. The supernatant liquid was then subjected to ultracentrifugation at $150000 \mathrm{~g}$ for $90 \mathrm{~min}$ to produce highspeed supernatant (HSS; cytosolic) and pellet (membrane) fractions. The pellet was resuspended in the original volume of phosphate buffer and washed by an additional high-speed centrifugation before it and other fractions were assayed for cyanide conversion activity as described below. The protein content in cell-extract fractions was determined by the Lowry procedure. $\mathrm{NAD}^{+}$was removed from HSSs by incubation with $0 \cdot 2 \mathrm{U}$ NADase $\left(\mathrm{NAD}^{+}\right.$glycohydrolase; EC 3.2.2.5) $\mathrm{ml}^{-1}$ for $1 \mathrm{~h}$ at $30^{\circ} \mathrm{C}$.

Cyanide-degradation assay. The time-dependent disappearance of cyanide (CDA) was measured in sealed vials $(15 \mathrm{ml}$ Hypo-Vials crimp-sealed with Tuf-Bond Teflon-rubber laminated discs, Pierce Chemical, or $2 \mathrm{ml} \mathrm{HPLC}$ screw-cap autosampler vials sealed with silicon rubber/PTFE septa, Rainin Instrument) at $30^{\circ} \mathrm{C}$ by an adaptation of the procedure described previously for intact cells (Kunz et al., 1992). The standard reaction mixture contained in $0.25 \mathrm{ml}$ : cell extract (9$10 \mathrm{mg}$ protein $\mathrm{ml}^{-1}$ ), $2 \mathrm{mM} \mathrm{KCN}, 4 \mathrm{mM} \mathrm{NADH}$ (where indicated), and $50 \mathrm{mM} \mathrm{Na}-\mathrm{K}$ buffer, $\mathrm{pH} 7 \cdot 0$. Reactions were initiated by the injection of $\mathrm{KCN}$ and $25 \mu \mathrm{l}$ samples were withdrawn at intervals and diluted as necessary for the determination of cyanide by the method of Lambert et al. (1975). Separate reaction vials containing cell extract incubated in the absence of cyanide were also included as a reference for colorimetric determinations. Reaction mixtures were made anaerobic by flushing vials with oxygen-free $\mathrm{N}_{2}$ for 5 min prior to injecting $\mathrm{KCN}$.

Determination of cyanide reaction products and stoichiometries. The products of cyanide metabolism were quantified in reaction mixtures containing either 2 or $25 \mathrm{mM} \mathrm{KCN}$ supplied as the ${ }^{12} \mathrm{C}$-, ${ }^{13} \mathrm{C}$ - or ${ }^{14} \mathrm{C}$-isotopic species. Reactions were carried out in sealed vials as described above, or in serum-stoppered flasks when radioactive ${ }^{14} \mathrm{CO}_{2}$ production from cyanide was determined. In the latter case, the main compartment of a $25 \mathrm{ml}$ 
serum-stoppered flask fitted with a centre well contained $0 \cdot 4 \mathrm{ml}$ cell extract $\left(9.10 \mathrm{mg}\right.$ protein $\mathrm{ml}^{-1}$; HSS), NADH (where indicated) and $50 \mathrm{mM} \mathrm{Na}-\mathrm{K}$ phosphate buffer, $\mathrm{pH} 7 \cdot 0$, in a total volume of $0.5 \mathrm{ml}$. The reaction was initiated by the injection of labelled (1 $2.5 \mu \mathrm{Ci} ; 37-92.5 \mathrm{kBq})$ and unlabelled $\mathrm{KCN}(2$ or $25 \mathrm{mM}$ ), and when reactions were complete, as determined by simultaneous assays for cyanide, $0.3 \mathrm{ml} 4 \mathrm{M} \mathrm{NaOH}$ was injected into the centre well. The flask was incubated for an additional 15 min to trap volatile ${ }^{14} \mathrm{CO}_{2}$ and the contents of the main compartment and centre well were fractionated with $\mathrm{BaCl}_{2}$ as previously described (Fallon et al., 1991; Kunz et al., 1992). $\mathrm{CO}_{2}$ was thus quantified as the sum of the radioactivity recovered in the centre well (volatile ${ }^{14} \mathrm{CO}_{2}$ ) and main compartments (non volatile $\left.\mathrm{H}^{14} \mathrm{CO}_{3}^{-}\right)$. The identity of $\mathrm{CO}_{2}$ as a reaction product was also verificed by the detection of a $45 \mathrm{~m} / \mathrm{e}$ species when the headspace from incubations conducted with $\mathrm{K}^{-13} \mathrm{CN}$ as the substrate was analysed by mass spectrometry. This was accomplished by injecting $10 \mu \mathrm{l}$ gas over a polydimethylsiloxane capillary column (Alltech Associates SE3-30M) coupled to a Hewlett-Packard 5992 GCMS equipped with a Teknivent Vector-One data acquisition system.

The quantification of formic acid and formamide in reaction mixtures supplied either isotopic or nonisotopic cyanide was determined following deproteinization of samples by treatment with $0.6 \mathrm{M} \mathrm{ZnSO}_{4}$. For this purpose, $10 \mu \mathrm{l} 6 \mathrm{M} \mathrm{ZnSO}_{4}$ was added to $100 \mu \mathrm{l}$ sample and protein removed by centrifugation in a microcentrifuge. Formic acid in the supernatant was then determined enzymically using commercial formate dehydrogenase as described previously (Kunz et al., 1992). The identity of formic acid was further confirmed by GCMS. This was accomplished by injecting $10 \mu \mathrm{l}$ of the reaction mixture onto an Alltech Associates AT1000 $10 \mathrm{~m}$ megabore column (injector $110^{\circ} \mathrm{C}$, flow $6.5 \mathrm{ml} \mathrm{min}^{-1} \mathrm{He}$, oven programmed at $40^{\circ} \mathrm{C}$ for $2 \mathrm{~min}$, then ramped to $110^{\circ} \mathrm{C}$ at $10^{\circ} \mathrm{C} \mathrm{min}^{-1}$ ) fitted to a mass spectrometer. The retention time was $9 \mathrm{~min}$ and masses of 46 $\left(\mathrm{H}^{12} \mathrm{COOH}\right)$ and $47 \mathrm{~m} / e\left(\mathrm{H}^{13} \mathrm{COOH}\right)$ were detected, respectively, in incubations conducted with $\mathrm{K}^{-12} \mathrm{CN}$ and $\mathrm{K}^{-13} \mathrm{CN}$. The presence of formamide in deproteinized samples was determined colorimetrically (Fry \& Millar, 1972; Kunz et al., 1992) and by chemical hydrolysis to formic acid, which was then determined enzymically. The latter procedure was used when the concentration of formamide was below that which could be detected colorimetrically $(\leqslant 0 \cdot 2 \mathrm{mM})$. Formamide hydrolysis was achieved by adding $10 \mu \mathrm{l} 3 \mathrm{M} \mathrm{H}_{2} \mathrm{SO}_{4}$ to $90-100 \mu \mathrm{l}$ deproteinized sample in a microcentrifuge tube and allowing the mixture to incubate at $95^{\circ} \mathrm{C}$ for $2 \mathrm{~h}$, after which the sample was neutralized with $5 \mathrm{M} \mathrm{NaOH}$ and assayed enzymically for formate.

Ammonia was determined colorimetrically using the indophenol method of Fawcett \& Scott (1960). All spectrophotometric analyses were carried out on a Perkin-Elmer Lambda 6 spectrophotometer.

Oxidation of formic acid. The oxidation of formic acid to $\mathrm{CO}_{2}$ was determined radioisotopically by fractionation of reaction mixtures with $\mathrm{BaCl}_{2}$ as described earlier for ${ }^{14} \mathrm{CO}_{2}$ quantification from cranide. Reactions were initiated by the injection of $1-2.5 \mu \mathrm{Ci}(37-92.5 \mathrm{kBq})$ sodium $\left[{ }^{14} \mathrm{C}\right]$ formate $(0.5 \mathrm{mM})$, and $\mathrm{NAD}^{+}$, where supplied, was provided at $1 \mathrm{mM}$.

Formate dehydrogenase activity in cell extracts was measured spectrophotometrically as described by Höpner \& Knappe (1974) and Kunz et al. (1992). Activity was measured anaerobically where indicated by flushing cuvettes with oxygen-free $\mathrm{N}_{2}$ for 5 min prior to injecting HSS.

Chemicals. KCN (97\%), KOCN (99\%), $\mathrm{K}^{13} \mathrm{CN}$ (99 atom \%) and sodium $\left[{ }^{13} \mathrm{C}\right]$ formate $(99$ atom $\%$ ) were purchased from Aldrich. $\mathrm{K}^{-14} \mathrm{CN}\left(54 \mathrm{mCi} \mathrm{mmol}^{-1} ; 1998 \mathrm{MBq} \mathrm{mmol}^{-1}\right)$ and $\mathrm{Na}$ $\left[{ }^{14} \mathrm{C}\right]$ formate $\left(49 \mathrm{mCi} \mathrm{mmol}^{-1} ; 1813 \mathrm{MBq} \mathrm{mmol}^{-1}\right)$ were ob- tained from DuPont (NEN Research Products). Tcn was prepared as previously described (Silva-Avalos $e t$ al., 1990). All other chemicals were from standard commercial sources.

\section{RESULTS}

\section{Recovery of CDA in cell-free extracts}

As a first step in identifying the enzymes responsible for cyanide degradation in NCIMB 11764 efforts were made to recover CDA in cell-free extracts. As previously reported for intact cells (Kunz et al., 1992), cell extracts catalysed the time-dependent disappearance of cyanide at concentrations as high as $100 \mathrm{mM}\left(2600 \mathrm{mg} \mathrm{CN}^{-} \mathrm{l}^{-1}\right)$. Fractionation of crude extracts into cytosolic $(150000 \mathrm{~g}$; HSSs) and membrane (pellet) fractions revealed that the bulk $(90 \%)$ of CDA was located in the cytosolic fraction. Fig. 2 shows the rate at which cyanide was consumed when supplied at low concentration $(2 \mathrm{mM})$ under various reaction conditions. The fastest rate of cyanide consumption was observed when both oxygen and NADH were supplied, but activity in the absence of NADH or in reactions conducted anaerobically could still be detected. Fig. 3 shows the effect of protein concentration on CDA measured at a starting concentration of $10 \mathrm{mM} \mathrm{KCN}$. Under both aerobic (in the presence of NADH) and anaerobic (in the absence of NADH) conditions activity was protein-concentration dependent. Non-enzyme controls indicated that $<1 \%$ of cyanide disappeared due to loss of volatile $\mathrm{HCN}$ during incubation. Approximately $50 \%$ of the initial activity measured at $2 \mathrm{mM}$ cyanide (cyanide oxygenase) was lost after $3-4 \mathrm{~d}$ storage at $4{ }^{\circ} \mathrm{C}$, but when extracts were stored at $-20{ }^{\circ} \mathrm{C}$ greater than $90 \%$ of the initial activity was retained after $1-2$ months.

\section{Kinetics of cyanide conversion}

The kinetics of cyanide degradation were investigated under various reaction conditions including: aerobically

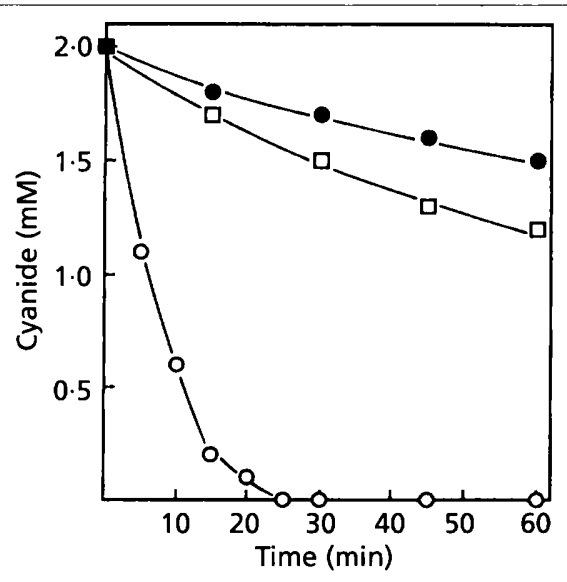

Fig. 2. Time-course of consumption of $2 \mathrm{mM}$ cyanide by HSSs from $P$. fluorescens NCIMB 11764 measured under the following reaction conditions: $O$, oxygen and NADH both present; $\square$, oxygen present, NADH absent; both oxygen and NADH absent. Reactions were conducted as described in Methods. Data represent the mean and mean deviations from two separate experiments. 


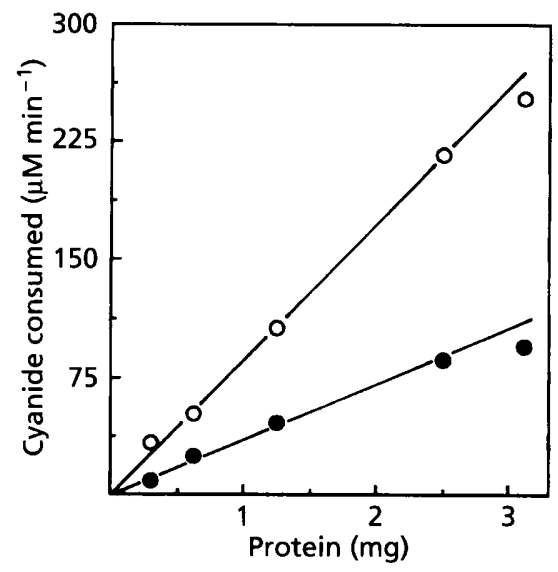

Fig. 3. Cyanide-degrading activity from P. fluorescens NCIMB 11764 measured as a function of protein concentration. Activities were measured at $10 \mathrm{mMKCN}$ under aerobic conditions (with $20 \mathrm{mMNADH}$; O) or anaerobic (without $\mathrm{NADH} ;-$ ) conditions. Data represent the mean and mean deviations from two separate experiments.

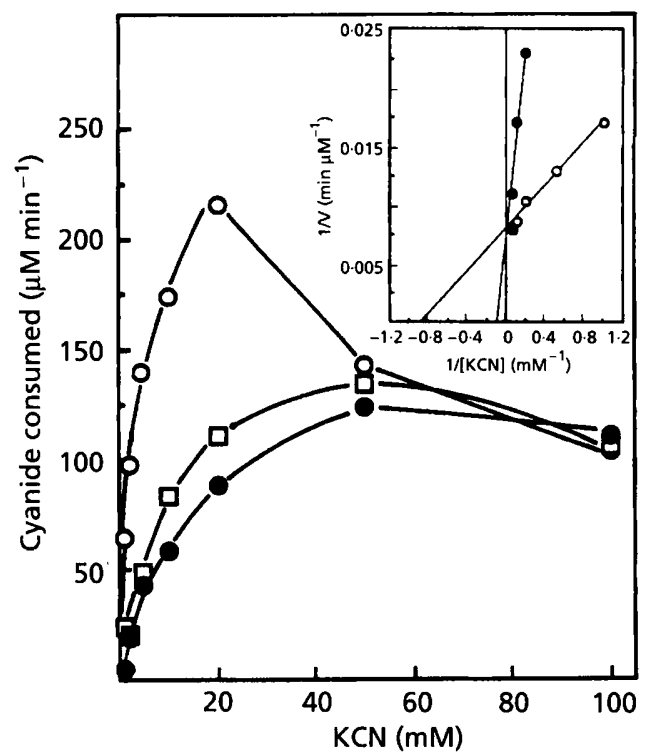

Fig. 4. Kinetics of cyanide degradation by HSSs from $P$. fluorescens NCIMB 11764. Rates of cyanide disappearance were measured in different sealed vials containing HSS (9-10 $\mathrm{mg}$ protein $\mathrm{ml}^{-1}$ ) and $\mathrm{KCN}$ at concentrations ranging from 1-100 mM. NADH where supplied was provided at a twofold excess over KCN. Reaction conditions: O, aerobic with NADH present; $\square$, aerobic with NADH absent; 0 , anaerobic (without NADH). Insert: Lineweaver-Burk plot of initial aerobic (with $\mathrm{NADH}$ ) rates $(O)$ after subtracting anaerobic (without NADH) rates (O). Data shown are representative data from three separate experiments.

with NADH present, aerobically with NADH absent, and under anaerobic conditions (without NADH). Fig. 4 shows that the initial rate of cyanide consumption increased as a function of substrate concentration under all three reaction conditions. The highest rate of substrate consumption was again observed when both oxygen and
NADH were supplied, with maximal activity recorded at $20 \mathrm{mM}$ cyanide; above this the activity declined probably due to enzyme inhibition. A second activity functioning in the absence of oxygen (and NADH) was also apparent at cyanide concentrations as high as $100 \mathrm{mM}$. Rates of substrate consumption measured aerobically in the absence of NADH fell between those recorded under aerobic and anaerobic conditions, suggesting that this activity represented the contribution of at least two enzymes. Noteworthily, rates of substrate consumption under all three reaction conditions appeared to follow MichaelisMenten kinetics; this despite the fact that more than a single activity appeared to be present in HSSs. In order to further differentiate between the various activities, rates of substrate consumption were further compared after initial rates recorded under anaerobic conditions (without $\mathrm{NADH}$ ) were subtracted from those obtained under aerobic conditions (with NADH present). In this way enzymes contributing to the total CDA in HSSs could be distinguished on the basis of favoured reaction conditions. This allowed the apparent kinetic constants (denoting the use of non-purified enzyme preparations) for the different enzymes to be estimated without each enzyme having to be individually purified. The insert to Fig. 4 shows the results obtained when the corrected data were replotted in the Lineweaver-Burk form. Dramatically different $K_{\mathrm{m}}$ values for cyanide were observed. Under aerobic conditions the apparent $K_{\mathrm{m}}$ was estimated at $1.2 \mathrm{mM}$ compared with $12 \mathrm{mM}$ under anaerobic conditions. We concluded from these observations that one enzyme in HSSs had a low apparent $K_{\mathrm{m}}$ and was both oxygen- and NADH-dependent, and a second enzyme had a high apparent $K_{\mathrm{m}}$ and required neither oxygen or NADH. In contrast to the differences observed in apparent $K_{\mathrm{m}}$, the apparent $V_{\max }$ values for the two were found to be essentially identical (125 $\mu \mathrm{M} \mathrm{min}^{-1}$; Fig. 4 insert).

\section{Reaction products and stoichiometries}

In order to identify the enzymes showing different cyanide-degrading kinetics the reaction products formed after incubating HSSs with cyanide at concentrations favouring one or the other activity were determined. Accordingly incubations were conducted at 2 and $25 \mathrm{mM} \mathrm{KCN}$, which were considered optimal, respectively, for the apparent low and high $K_{\mathrm{m}}$ activities. Table 1 shows that greater than $90 \%$ of the cyanide carbon was recovered as $\mathrm{CO}_{2}$, formic acid and formamide under all reaction conditions. In contrast, the accumulation of cyanide-nitrogen equivalents as formamide plus ammonia varied substantially (39-93 molar\%). This is because ammonia was apparently further metabolized, particularly under prolonged incubation periods when cyanide was supplied at low concentration $(2 \mathrm{mM})$. Therefore, the molar ratios of formamide:ammonia accumulated at $2 \mathrm{mM} \mathrm{KCN}$ under aerobic (with NADH present) and anaerobic (without NADH) conditions were only $10: 31$ and 32:7 (41 and 39\% molar recovery), respectively. This compares with values of $56: 37$ and $53: 40$, respectively, for corresponding reactions conducted at $25 \mathrm{mM}$.

As previously also reported using intact cells (Kunz et al., 
Table 1. Products of cyanide metabolism by cell-free extracts of $P$. fluorescens NCIMB 11764

Experiments were conducted in sealed vials containing air or $\mathrm{N}_{2}$ in the gas phase. Reaction mixtures contained HSS (9-10 $\mathrm{mg}$ protein $\mathrm{ml}^{-1}$ ) prepared from cyanide-grown cells and $\mathrm{NADH}$, where indicated, at twice the concentration of $\mathrm{KCN}$. After $\geqslant 90 \%$ of the cyanide was consumed, reaction products were determined by the analytical methods described in Methods. Data shown are the means and mean deviations from at least two separate experiments.

\begin{tabular}{|lcccccc|}
\hline Reaction conditions & \multirow{2}{*}{$\begin{array}{c}\text { KCN } \\
\text { consumed } \\
(\mathbf{m M})\end{array}$} & $\begin{array}{c}\text { Incubation } \\
\text { time }\end{array}$ & \multicolumn{3}{c|}{ Products formed (nmol per $\boldsymbol{\mu m o l ~ K C N )}$} \\
\cline { 5 - 7 } & $\mathbf{( h )}$ & $\mathbf{C O}_{2}$ & Formic acid & Formamide & Ammonia \\
\hline Aerobic (with NADH) & 2 & $0 \cdot 25$ & $871 \pm 51$ & $60 \pm 8$ & $102 \pm 1$ & $308 \pm 2$ \\
Anaerobic (without NADH) & 25 & 5 & $488 \pm 40$ & $65 \pm 42$ & $370 \pm 28$ & $562 \pm 88$ \\
& 25 & 3 & $86 \pm 11$ & $692 \pm 89$ & $324 \pm 105$ & $67 \pm 46$ \\
& 10 & $230 \pm 42$ & $418 \pm 110$ & $405 \pm 87$ & $489 \pm 116$ \\
\hline
\end{tabular}

1992), the relative yield of carbon compounds recovered after HSSs were incubated with cyanide varied with the reaction conditions and concentration of cyanide supplied. For example, the molar ratios of $\mathrm{CO}_{2}$ : formic acid: formamide measured at 2 and $25 \mathrm{mM} \mathrm{KCN}$ under aerobic conditions were $87: 6: 10$ and 49:6:37. These results indicated that the major carbon-derived product obtained when both oxygen and NADH were supplied was $\mathrm{CO}_{2}$. It was therefore concluded that an enzyme similar to cyanide oxygenase as previously described (Harris \& Knowles, 1983b) was responsible for $\mathrm{CO}_{2}$ formation. Because of the rapid consumption of cyanide by the putative cyanide oxygenase ( $15 \mathrm{~min}$ for $2 \mathrm{mM}$ ), it was further concluded that it was this enzyme that displayed the lower apparent $K_{\mathrm{m}}$ for cyanide as indicated from kinetic studies. By comparison, the molar ratios of products formed at 2 and $25 \mathrm{mM} \mathrm{KCN}$ under anaerobic conditions were 9:69:32 and 23:42:40, respectively, indicating that while $\mathrm{CO}_{2}$ was still made (for reasons discussed below), the major reaction products were formic acid and formamide. Detection of the latter chemical species is consistent with the reaction products expected for cranide nitrilase and hydratase enzymes as earlier proposed (Kunz et al., 1992). The detection of $\mathrm{CO}_{2}$ under anaerobic conditions was a surprise until it was discovered that formate was subject to further oxidation as outlined below.

\section{Oxidation of formic acid by inducible formate dehydrogenase}

The detection of $\mathrm{CO}_{2}$ under various reaction conditions (Table 1) raised the possibility that in addition to its direct formation from cyanide, it could also arise from the oxidation of formate. To test this possibility, HSSs were incubated with $\left[{ }^{14} \mathrm{C}\right]$ formate and the production of ${ }^{14} \mathrm{CO}_{2}$ (and $\mathrm{H}^{14} \mathrm{CO}_{3}^{-}$) was determined as described in Methods. Two separate experiments were conducted and the \% molar rields of $\mathrm{CO}_{2}$ are reported as the means and mean deviations. As much as $25 \pm 2 \%$ of the formate supplied to HSSs was recovered as $\mathrm{CO}_{2}$ after $2.5 \mathrm{~h}$ incubation; however, this was observed to increase to $88 \pm 3 \%$ when reaction mixtures were supplied with $\mathrm{NAD}^{+}$. These results suggested that formate oxidation was linked to an $\mathrm{NAD}^{+}$-dependent formate dehydrogenase present in HSSs. This was verified spectrophotometrically by observing the rapid formation of NADH when HSSs were added to reaction cuvettes containing both formate and $\mathrm{NAD}^{+}$. Activity was observed under both aerobic and anaerobic conditions, was protein-concentration dependent, and was inducible; the specific activity in HSSs from cyanide-grown cells was $14.0 \pm 3.4 \mathrm{nmol} \mathrm{NADH}$ formed $\min ^{-1}$ (mg protein) ${ }^{-1}$ compared with $<0.5 \mathrm{nmol} \mathrm{min}{ }^{-1}$ $(\mathrm{mg} \text { protein })^{-1}$ for cells grown on ammonia. The conversion of formate to $\mathrm{CO}_{2}$ in $25 \%$ molar yield in incubations from which $\mathrm{NAD}^{+}$was omitted was somewhat of a surprise. We hypothesized that this might be due to the presence of endogenous $\mathrm{NAD}^{+}$in HSSs available for formate dehydrogenase activity. The removal of $\mathrm{NAD}^{+}$, therefore, should result in a decrease in the yield of $\mathrm{CO}_{2}$, and in fact this was observed when HSSs were pretreated with NADase prior to incubation with $\left[{ }^{14} \mathrm{C}\right]$ formate. In this case the recovery of $\mathrm{CO}_{2}$ from formate decreased to $4.8 \pm 1 \cdot 7 \%$.

\section{Effect of formate and NAD+ on cyanide oxygenase activity}

The discovery of formate dehydrogenase in $P$. fuorescens NCIMB 11764 suggested that the $\mathrm{NAD}^{+}$-driven oxidation of formate might provide a means of generating the NADH utilized by cyanide oxygenase. To explore this possibility, the effect of $\mathrm{NAD}^{+}$and formate on both cyanide oxygenase activity and the corresponding molar conversion yield of cyanide into $\mathrm{CO}_{2}$ were tested, the rationale being that if these compounds were involved in $\mathrm{NADH}$ recycling an effect on both enzymic activity and production of $\mathrm{CO}_{2}$ might be observed. Table 2 shows that when reactions were conducted with extracts that were pretreated with NADase, both cyanide oxygenase activity and the corresponding $\mathrm{CO}_{2}$ yield were substantially lower than in comparable reactions in which untreated HSSs were employed. However, when reactions were supplemented with $\mathrm{NAD}^{+}$, both the $\mathrm{CDA}$ and $\mathrm{CO}_{2}$ yield increased to 67 and $46 \%$ of maximal, and when both $\mathrm{NAD}^{+}$and formate were supplied, these increased to 98 
Table 2. Effect of formate and $N A D^{+}$on putative cyanide oxygenase activity in $P$. fluorescens NCIMB 11764

Reactions were conducted with $2 \mathrm{mM} \mathrm{KCN}$ in sealed vials with an air atmosphere. $\mathrm{NADH}, \mathrm{NAD}^{+}$and formate where supplied were provided at $4 \mathrm{mM}$. Data shown are the means and mean deviations from at least two separate experiments. Numbers in parentheses represent values relative to that obtained for reactions with $\mathrm{NADH}$ supplied.

\begin{tabular}{|lcc|}
\hline Reaction conditions & $\begin{array}{c}\text { Cyanide } \\
\text { oxygenase } \\
\text { [nmol min }{ }^{-1} \\
\left.\text { (mg protein) }{ }^{-1}\right]^{*}\end{array}$ & $\begin{array}{c}\text { \% Molar yield } \\
{ }^{14} \mathbf{C O}_{\mathbf{2}} \text { from } \\
\mathbf{K}^{14} \mathbf{C N} \dagger\end{array}$ \\
\hline NADH & $12 \cdot 6 \pm 1 \cdot 4(100)$ & $87 \cdot 1 \pm 5 \cdot 1(100)$ \\
No NADH & $2 \cdot 6 \pm 0 \cdot 6(21)$ & $25 \cdot 1 \pm 2 \cdot 8(29)$ \\
NADase-treated HSS & $1 \cdot 2 \pm 0 \cdot 3(10)$ & $3 \cdot 6 \pm 0 \cdot 8(4)$ \\
NAD & $8 \cdot 5 \pm 1 \cdot 2(67)$ & $39 \cdot 6 \pm 0 \cdot 6(46)$ \\
Formate & $2 \cdot 4 \pm 0 \cdot 4(19)$ & $18 \cdot 2 \pm 2 \cdot 4(21)$ \\
NAD $^{+}+$formate & $12 \cdot 4 \pm 1 \cdot 6(98)$ & $87 \cdot 2 \pm 1 \cdot 3(100)$ \\
\hline
\end{tabular}

* Calculated from initial rates of cyanide consumption by HSSs from cyanide-grown cells.

†Determined as the sum of volatile $\mathrm{CO}_{2}$ and non-volatile $\mathrm{HCO}_{3}^{-}$ collected after $\geqslant 90 \%$ of the substrate was consumed.

and $100 \%$, respectively. In contrast, the addition of formate alone had no significant effect on either enzymic activity or $\mathrm{CO}_{2}$ production. A role for both formate and $\mathrm{NAD}^{+}$in the recycling of NADH was thus inferred.

\section{Isolation and characterization of cyanide metabolic mutants}

Experiments were performed to determine whether one of the CDAs was more important physiologically for cyanide utilization. To accomplish this, a mutant strain
(JL102) that was no longer able to grow on cyanide was isolated and the effect on expression of cyanide oxygenase and cyanide nitrilase/hydratase activities was determined. Since the mutant was unable to grow, this necessitated testing for the induction of enzymic activity under nongrowth conditions. For this purpose, cells were grown to stationary phase in a nitrogen-limiting medium and induced with cyanide as described in Methods. Under these conditions cyanide oxygenase could be detected in induced wild-type cells and, as shown in Table 3 , the level of activity was actually higher than that detected in wildtype cells grown on cyanide. In contrast, the level of cyanide nitrilase/hydratase activities in induced cells of the wild-type was lower than in cultivated cells, suggesting that the regulation of synthesis of cyanidedegrading enzymes in NCIMB 11764 may be different. When HSSs from induced cells of the mutant strain JL102 were tested for cyanide oxygenase no activity was detected, but the level of cyanide nitrilase/hydratase enzymes was similar to that present in the wild-type. We concluded from these results that the inability of JL102 to grow on cyanide was related to its inability to produce cyanide oxygenase.

In order to determine the involvement of cyanate as a possible intermediate in cyanide metabolism as earlier proposed (Harris \& Knowles, 1983b) a mutant strain (ON101) unable to grow on cyanate was isolated (Nagappan, 1992) and the effect on cyanide utilization determined. This mutant, while unable to grow on cyanate (phenotype designation $\mathrm{Cnt}^{-}$), could still utilize cyanide ( $\mathrm{Tcn}$ or $\mathrm{KCN}$, phenotype designation $\mathrm{Cn}^{+}$) as a nitrogen source. By comparison, strain JL102 having lost the ability to grow on cyanide $\left(\mathrm{Cn}^{-}\right)$was unaffected in cyanate utilization $\left(\mathrm{Cnt}^{+}\right)$.

\section{DISCUSSION}

The recovery of putative cyanide oxygenase and cyanide nitrilase/hydratase enzymes in HSSs is consistent with an

\section{Table 3. Synthesis of CDAs in wild-type and mutant strains of $P$. fluorescens NCIMB 11764}

Data shown are the means and mean deviations from at least two separate experiments using HSSs prepared from cells cultivated under the following conditions.

\begin{tabular}{|c|c|c|c|}
\hline \multirow[t]{2}{*}{ Strain } & \multirow{2}{*}{$\begin{array}{l}\text { Cultivation } \\
\text { conditions* }\end{array}$} & \multicolumn{2}{|c|}{ Specific activity $\left[\mathrm{nmol} \mathrm{min}^{-1}(\mathrm{mg} \text { protein })^{-1}\right] \dagger$} \\
\hline & & $\begin{array}{c}\text { Cyanide } \\
\text { oxygenase }\end{array}$ & $\begin{array}{c}\text { Cyanide } \\
\text { nitrilase/hydratase }\end{array}$ \\
\hline Wild-type & $\begin{array}{l}\text { Cyanide-grown } \\
\text { Cyanide-induced } \\
\text { Ammonia-grown }\end{array}$ & $\begin{array}{l}12 \cdot 6 \pm 1 \cdot 4 \\
29 \cdot 5 \pm 2 \cdot 5 \\
\quad<0.5\end{array}$ & $\begin{array}{c}11 \cdot 8 \pm 1 \cdot 3 \\
1 \cdot 7 \pm 0 \cdot 5 \\
<0.5\end{array}$ \\
\hline JL102 & $\begin{array}{l}\text { Cyanide-induced } \\
\text { Ammonia-grown }\end{array}$ & $\begin{array}{l}<0.5 \\
<0.5\end{array}$ & $\begin{array}{c}1 \cdot 3 \pm 0 \cdot 4 \\
<0.5\end{array}$ \\
\hline
\end{tabular}

* Procedures for the growth and induction of cells are described in Methods.

† Measured as initial rates of cyanide disappearance. Cyanide oxygenase activity was measured aerobically (with $\mathrm{NADH}$ present) at $2 \mathrm{mM} \mathrm{KCN}$ and was uncorrected for cyanide nitrilase/hydratase activity measured anaerobically (without $\mathrm{NADH}$ ) at $25 \mathrm{mM} \mathrm{KCN}$. 


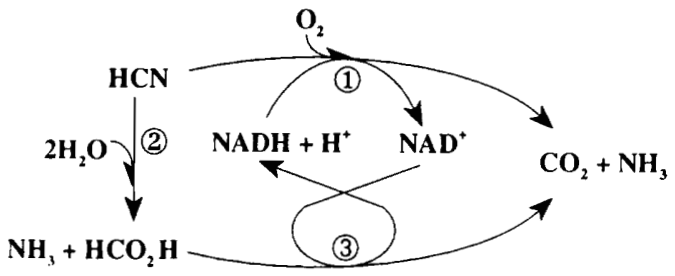

Fig. 5. Pathways of cyanide transformation in $P$. fluorescens NCIMB 11764 showing the role of cyanide oxygenase (1), cyanide nitrilase (2) and formate dehydrogenase (3) in regenerating pyridine nucleotide cofactors.

earlier report from this laboratory indicating that cyanide is metabolized by more than a single mechanism in $P$. fuorescens NCIMB 11764 (Kunz et al., 1992). Results showing that one of these, cyanide oxygenase, generated $\mathrm{CO}_{2}$ (and $\mathrm{NH}_{3}$ ) as reaction products (Table 1), and that activity was dependent both on oxygen and $\mathrm{NADH}$, find analogy with previous reports in which initial cyanide degradation was proposed to be oxygenase-mediated (Harris \& Knowles, 1983b). We have further independently confirmed the findings of Harris \& Knowles (1983b) in which 1 mol oxygen and $1 \mathrm{~mol} \mathrm{NADH}$ were reported to be consumed per mol cyanide degraded by this enzyme (C. S. Wang \& D. A. Kunz, unpublished results). Lnequivocal proof, however, that catalysis is oxygenase-mediated will require that the incorporation of ${ }^{18} \mathrm{O}$ into the product be demonstrated, but this may not be possible since $\mathrm{CO}_{2}$ rapidly exchanges its oxygens with water (Pocker \& Bjorkquist, 1977; Knowles, 1988). On the other hand, results showing that formate oxidation could be coupled to putative cyanide oxygenase activity (Table 2), apparently by recycling NADH (Fig. 5), further imply the involvement of an oxygenase-type mechanism.

The description of a combined activity containing both cyanide nitrilase/hydratase enzymes in cell-free extracts is consistent with previous work in which formic acid (and $\mathrm{NH}_{3}$ ) and formamide were identified as additional cyanide conversion products (Kunz et al., 1992). The increased production of these compounds relative to $\mathrm{CO}_{2}$ (and $\mathrm{NH}_{3}$ ) at higher substrate concentrations $(\geqslant 10 \mathrm{mM}$ ) (Table 1) can now be better explained on the basis of differences in substrate affinity between cyanide oxygenase and the nitrilase/hydratase enzymes. Thus, cyanide oxy'genase, with an estimated $K_{\mathrm{m}}$ of $1.2 \mathrm{mM}$, attacks cyanide more effectively at lower substrate concentration than does the combined activity of nitrilase/hydratase enzymes for which a combined apparent $K_{\mathrm{m}}$ of $12 \mathrm{mM}$ was estimated (Fig. 4). Although the apparent $K_{\mathrm{m}}$ values of the two are different, the catalytic rates of cyanide turnover for each are the same. At present, we are unable to say for certain whether the $\mathrm{CDA}$ having cyanide nitrilase/ hydratase activities consists of one or two enzymes. Data showing no inconsistencies in the apparent MichaelisMenten kinetics of this activity (Fig. 4) suggest that only one enzvme is involved, but this does not agree with the observation that both formic acid (and $\mathrm{NH}_{3}$ ) and formamide accumulate, and the fact that formamide, as shown previously (Kunz et al., 1992), is not further degraded. Thus, our working hypothesis is that there are two enzymes, a cyanide nitrilase (dihydratase) generating formic acid (and $\mathrm{NH}_{3}$ ), and a cyanide hydratase (EC 4.2.1.66) giving formamide. Both enzymes would be expected to function in the absence of oxygen, which is consistent with our observations. The occurrence of cyanide nitrilase in NCIMB 11764 finds analogy with several reports of related enzymes in cyanide-degrading bacteria (White et al., 1988; Ingvorsen et al., 1991; Meyers et al., 1993). These enzymes are believed to catalyse the direct hydrolysis of cyanide into formic acid and ammonia without the involvement of formamide as an intermediate. As such, they resemble true nitrilases (EC 3.5.5.1), but with a substrate range limited to cyanide. In contrast to cyanide nitrilases, cyanide hydratases have thus far been described only in phytopathogenic fungi (Fry \& Millar, 1972; Fry \& Evans, 1977; Fry \& Myers, 1981), making the description of such an enzyme in NCIMB 11764 the first of its kind in bacteria. However, additional studies are needed before firm conclusions regarding the description of this and other enzymes elaborated by NCIMB 11764 can be made. Towards this end, efforts aimed at separating and purifying these enzymes are currently in progress.

While the involvement of formate dehydrogenase in cyanide metabolism has previously been proposed (Knowles, 1976; Knowles \& Bunch, 1986), until now, direct evidence for this has not been provided. Its description thus adds a new dimension to cyanide metabolism by NCIMB 11764. As shown in Fig. 5, the production of $\mathrm{CO}_{2}$ can now be visualized as arising by two separate routes; one from the oxidation of cyanide by cyanide oxygenase and the other from the oxidation of formic acid, the latter arising via cyanide nitrilase activity. Data showing that both formate and $\mathrm{NAD}^{+}$enhanced cyanide oxygenase activity (Table 2) suggest that formate dehydrogenase could be involved in the recycling of $\mathrm{NADH}$ as further depicted in Fig. 5. It appears this enzyme is similar to other $\mathrm{NAD}^{+}$-linked formate dehydrogenases described in bacteria (Quayle, 1966; Ferry, 1990), but the first of its kind reported to be induced by cyanide. We hypothesize that this enzyme may be important in preserving NADH under conditions of cyanide poisoning. For example, in the presence of cyanide (serving as a nitrogen source) the extent of NADH utilization generated from glucose (serving as a carbon and energy source) via respiratory chain enzymes would be expected to be inhibited by cyanide (Solomonson, 1981). Therefore, the consumption of NADH by a non-energy yielding reaction such as that catalysed by cyanide oxygenase would be expected to compromise energy yields and thus cell growth, but this may be overcome if the NADH recycling mechanism proposed for formate dehydrogenase operates. The inhibitory effect of cyanide on respiration is further thought to explain why growth of NCIMB 11764 at concentrations exceeding $0.25 \mathrm{mM}$ is not observed (Silva-Avalos et al., 1990).

In summary, growth of $P$. fluorescens NCIMB 11764 on 
cyanide leads to the elaboration of several CDAs. Of these, cyanide oxygenase appears most important in initiating substrate attack at concentrations favourable for growth $(\leqslant 0 \cdot 25 \mathrm{mM})$. As a result cyanide is detoxified and ammonia is made available for assimilation by what are presumed to be established biochemical mechanisms (Tyler, 1978; Neidhardt et al., 1990). The fundamental importance of cyanide oxygenase in cyanide utilization is further illustrated by results showing that this enzyme is not produced in a mutant strain no longer able to grow on cyanide (Table 3 ). While it could be argued that cyanide nitrilase on its own should be sufficient to support growth because it too generates ammonia, we hypothesize that its low substrate affinity precludes it from functioning exclusively for this purpose. Thus, in contrast to cyanide oxygenase the roles of cyanide nitrilase and cyanide hydratase in NCIMB 11764 remain to be further elucidated. In addition, the observation that a mutant defective in cyanate utilization can still grow on cyanide (phenotype $\mathrm{Cn}^{+} \mathrm{Cnt}^{-}$) finds analogy with earlier reported enzymeinduction studies (Dorr \& Knowles, 1989; Nagappan, 1992) indicating that the enzymes involved in cyanide and cyanate metabolism are physiologically different.

\section{ACKNOWLEDGEMENTS}

We thank Dr O. Nagappan for isolating the cyanate-defective mutant. The assistance of Dr B. J. Venables, Trac Laboratories Inc., Denton, Texas, USA, in performing the GC/MS analysis is also graciously acknowledged. Dr P. J. Weimer assisted in the critical review of the manuscript. This work was funded by grant DCB 9104601 from the National Science Foundation.

\section{REFERENCES}

Dorr, P. K. \& Knowles, C. J. (1989). Cyanide oxygenase and cyanase activities of Pseudomonas fuorescens NCIMB 11764. FEMS Microbiol Lett 60, 289-294.

Fallon, R. D., Cooper, D. A., Speece, R. \& Henson, M. (1991). Anaerobic biodegradation of cyanide under methanogenic conditions. Appl Environ Microbiol 57, 1656-1662.

Fawcett, J. K. \& Scott, J. E. (1960). A rapid and precise method for the determination of urea. J Clin Patbol 13, 156- 159.

Ferry, J. G. (1990). Formate dehydrogenase. FEMS Microbiol Rev 87, 377-382.

Fry, W. E. \& Millar, R. L. (1972). Cyanide degradation by an enzyme from Stemphylium loti. Arch Biochem Biophys 151, 468-474.

Fry, W. E. \& Evans, P. H. (1977). Association of formamide hydrolyase with fungal pathogenicity to cyanogenic plants. Pbytopathology 67, 1001-1006.

Fry, W. E. \& Myers, D. F. (1981). Hydrogen cyanide metabolism by fungal pathogens of cyanogenic plants. In Cyanide in Biology, pp. 321-334. Edited by B. Vennesland, E. E. Conn, C. J. Knowles, J. Westely \& F. Wissing. London: Academic Press.

Harris, R. \& Knowles, C. J. (1983a). Isolation and growth of a Pseudomonas species that utilizes cyanide as a source of nitrogen. $J$ Gen Microbiol 129, 1005-1011.

Harris, R. E. \& Knowles, C. J. (1983b). The conversion of cyanide to ammonia by extracts of a strain of Pseudomonas fluorescens that utilizes cyanide as a source of nitrogen for growth. FEMS Microbiol Lett 20, 337-341.

Höpner, T. \& Knappe, J. (1974). Formate: determination with formate dehydrogenase. Methods of Enzymatic Analysis, vol. 3, pp. 1551-1555. Edited by H. U. Bergmeyer. New York: Academic Press.

Ingvorsen, K., Højer-Pederson, B. \& Godtfredsen, S. E. (1991). Novel cyanide-hydrolyzing enzyme from Alcaligenes xylosoxidans subsp. denitrificans. App/ Environ Microbiol 57, 1783-1789.

Knowles, C. J. (1976). Microorganisms and cyanide. Bacteriol Rel' 40, 652-680.

Knowles, C. J. (1988). Cyanide utilization and degradation by microorganisms. CIBA Found Symp 140, 3-15.

Knowles, C. J. \& Bunch, A. W. (1986). Microbial cyanide metabolism. Adv Microb Physiol 27, 73-111.

Kunz, D. A. \& Nagappan, O. (1989). Cyanase-mediated utilization of cyanate in Pseudomonas furoscens NCIMB 11764. Appl Entiron Microbiol 55, 256-258.

Kunz, D. A., Nagappan, O., Silva-Avalos, J. \& Delong, G. T. (1992). Utilization of cyanide as a nitrogenous substrate by Pseudomonas fluorescens NCIMB 11764: evidence for multiple pathways of metabolic conversion. Appl Environ Microbiol 58, 2022-2029.

Lambert, J. L., Ramasamy, J. \& Paukstells, J. V. (1975). Stable reagents for the colorimetric determination of cyanide by modified König reactions. Anal Chem 47, 916-918.

Meyers, P. R., Rawlings, D. E., Woods, D. R. \& Lindsey, G. G. (1993). Isolation and characterization of a cyanide dihydratase from Bacillus pumilus C1. J Bacteriol 175, 6105-6112.

Nagappan, O. (1992). Mechanisms of cyanide assimilation in Pseudomonas fuorescens NCIMB 11764. PhD thesis, University of North Texas, LSA.

Neidhardt, F. C., Ingraham, J. L. \& Schaechter, M. (1990). Pbysiology of the Bacterial Cell: a Molecular Approach. Sunderland, Massachusetts: Sinauer Associates.

Pocker, Y. \& Bjorkquist, D. W. (1977). Stopped-flow studies of carbon dioxide hydration and bicarbonate dehydration in $\mathrm{H}_{2} \mathrm{O}$ and $\mathrm{D}_{2} \mathrm{O}$. Acid-base and metal ion catalysis. J Am Chem Soc 99, 6537- 6543 .

Quayle, J. R. (1966). Formate dchydrogenase. Methods Enzymol 9 , 360-364.

Rollinson, G., Jones, R., Meadows, M. P., Harris, R. E. \& Knowles, C. J. (1987). The growth of a cyanide-utilising strain of Pseudomonas fluorescens in liquid culture on nickel cyanide as a source of nitrogen. FEMS Microbiol Lett 40, 199-205.

Silva-Avalos, J., Richmond, M. G., Nagappan, O. \& Kunz, D. A. (1990). Degradation of the metal-cyano complex tetracyanonickelate (II) by cyanide-utilizing bacterial isolates. Appl Environ Microbiol 56, 3664-3670.

Solomonson, L. P. (1981). Cyanide as a metabolic inhibitor. In Cyanide in Biology, pp. 11-28. Edited by B. Vennesland, E. E. Conn, C. J. Knowles, J. Westley \& F. Wissing. London: Academic Press.

Tyler, B. (1978). Regulation of the assimilation of nitrogen compounds. Annu Rev Biochem 47, 1127-1162.

White, J. M., Jones, D. D., Huang, D. \& Gauthier, J. J. (1988). Conversion of cyanide to formate and ammonia by a pseudomonad obtained from industrial wastewater. J Ind Microbio/ 3, 263-272.

Received 14 December 1993; revised 1 March 1994; accepted 10 March 1994. 